\title{
Understanding Entrepreneurial Intentions among Undergraduate Students: Applying Theory of Planned Behavior
}

\author{
Fayeq Ali Ali ${ }^{1}$ \\ ${ }^{1}$ Department of Business and Management, Tishk International University, Erbil, Iraq. \\ Correspondence: Fayeq Ali Ali, Tishk International University, Erbil, Iraq. \\ Email: fayeq.ali@tiu.edu.iq
}

Doi: $10.23918 /$ ijsses.v8i2p222

\begin{abstract}
The main aim behind this study is to understand the level of entrepreneurial intentions among students by applying the TPB. Data were collected among students from five different departments with 219 filled questionnaires. Data got analyzed by using SPSS V. 25 for frequencies, correlation, and regression. Findings discloses that the theory of planned behavior positively affects entrepreneurial intentions. Also, the strong relationship between TPB and EI is from the perceived behavioral control, after comes the personal attitude and subjective norms from public universities. The research concluded, there are differences between the effect and relationship of TPB on EI in a different type of universities and might be due to factors such as ways of teaching, curriculum, social and economic. The study also found that $\mathbf{7 2 . 6 \%}$ have good and full information about the competencies needed to become an entrepreneur and the main challenge they face for being an entrepreneur is self-confidence.
\end{abstract}

Keywords: Theory of Planned Behavior, Entrepreneurial Intentions, Self-confidence

\section{Introduction}

The current research aims to understand entrepreneurial intentions among undergraduate students at public universities in Erbil, by applying the theory of planned behavior. This research seeks to know how students have acquired entrepreneurial intentions from a behavioral approach. The other objective of this study is to find out if there are differences among different contexts and what the main challenges students face are after getting some entrepreneurial competencies/whether they got enough competencies from provided courses.

The significance of entrepreneurship in shaping and developing firms for the economic development of a country is broadly acknowledged (Ahktar, Azeem \& Mir, 2014). Entrepreneurship literature proves to recognize factors that new business establishment depends on entrepreneurship activities, because of its effect on economic development (Fuller et al., 2018). According to Werthes et al. (2018), this can be achieved by entrepreneurs who are passionate and willing to form new businesses to achieve personal and economic satisfaction.

Received: March 19, 2021

Accepted: June 21, 2021

Ali, F.A. (2021). Understanding Entrepreneurial Intentions among Undergraduate Students: Applying Theory of Planned Behavior. International Journal of Social Sciences \& Educational Studies, 8(2), 222-231. 
Choices of forming a new business are about entrepreneurial behavior. According to Ajzen (1991), there is a positive relationship between behavior and intention for business implementation. Honig (2004) stated that the best prediction of entrepreneurial behavior is entrepreneurial intentions. Entrepreneurial intentions are the strong feelings of an individual to start a new business and it is one of the most important factors which determines entrepreneurial movement. Entrepreneurial intentions in those countries which are driven by unstapled economic factors feel more to engage and become their business owners, this is due to the inadequate employment opportunities for the income generation (Singer, Amoros, \& Moska, 2015). In their empirical research, Pfeifer, Sarlija, and Zekic Susac (2016) revealed that the main predictor of entrepreneurial intentions is entrepreneurial identity and self-efficacy. A study across European countries found that young people see studying in universities as a step to have a stable career path (Siger \& Monsen, 2015).

Higher education institutions and policymakers see entrepreneurship as one of the main concerns for economic development (Y1ldırım et al., 2016). Because of its positive impact on economic growth, entrepreneurship becomes an interesting topic for educators and universities. Entrepreneurship education might be mean to surge individuals to become entrepreneurs and force job creation, innovation, and better productivity in a specific context (Olsovska et al., 2015). Because of its importance, many countries practice entrepreneurship as an infrastructure in higher education (Walter \& Block, 2016). University students from Poland have a strong entrepreneurial intention compared to Slovak and Czech students, in their findings, they also stated that students gained enough soft skills from universities in changing their intention to entrepreneurial behavior (Okręglicka et al., 2017). Both monetary and nonmonetary conditions can influence the degree of entrepreneurship inside any nation. Youth is considered one of the assets on which the procedure of building a better society can rely (Szafraniec, 2011). Being fruitful in this field is essential not just as freedom from parental control, going out, monetary autonomy, yet in addition, following one's life and calling it desires, aspirations, and plans of building a new life of freedom. Work isn't just a kind of income, which for certain individuals implies an approach to endure, while for others a nice and agreeable life. For future businesspeople, work is an additional wellspring of fulfillment and a chance for self-awareness (Cuervo, Ribeiro, \& Roig, 2007). Therefore, business venture training/education provided by universities is vital to future business people, to empower their capability of development and prepare them in information and instruments to make their business fruitful. Also, new organizations need to work with individuals who can create a business, on account of their potential employability, which incorporates learning capacities and exclusive requirements towards their future (Baruch \& Gregoriou, 2017).

\subsection{Research questions}

1. Is there a positive effect of the theory of planned behavior (TPB) on entrepreneurial intentions (EI)?

2. Which variable of the theory of planned behavior has more relationship with entrepreneurial intentions?

3. What are some challenges students face in being entrepreneurs and the level of entrepreneurial competencies acquired? 


\subsection{Research Objectives}

This study aims to find out the relationship and effect of the theory of planned behavior (TPB) with and on entrepreneurial intentions (EI). Another objective of this study is to discover which (TPB) variables have more effect on (EI) among undergraduate students at public universities in Erbil, KRG.

\subsection{Hypotheses}

H1: Theory of Planned Behavior positively affects the Entrepreneurial Intentions.

H2: Perceived Attitude has a strong and positive correlation with Entrepreneurial Intentions.

H3: Subjective Norms have a strong and positive correlation with Entrepreneurial Intentions.

H4: Perceived Behavioral Control has a strong and positive correlation with entrepreneurial Intentions.

\section{Literature Review}

\subsection{Theory of Planned Behavior}

TPB is the theory which estimates and clarifies a particular behavior in a particular context (Renko et al., 2011). TPB is used in many other disciplines (Ajzen, 1991). This is also valid for entrepreneur-transport research since it turns a business into a visionary view as a cognizant movement and expectation taken to be an intellectual state (Ajzen, 1991). Additionally, it is stated that entrepreneurial choice is an unpredictable one and needs a deliberate psychological cycle. Subsequently, rather than character attributes or segment examines, cognizance contains more and critical data regarding entrepreneurial intention (Linan, 2008). Based on the theory of planned behavior there are two main foundations of intention: feasibility which contains and individual effects by the subjective norms and personal attitude toward a particular behavior and the second base is desirability as a motivational factor to control perceived behavior, which both shapes a person's entrepreneurial intentions. Subjective norms are shaped by culture and people around someone who wants to accomplish something for a reason especially entrepreneurial intentions for the establishment of a new business (Engle et al., 2010). Perceived attitude is solely about a person's like/dislike or willingness or not willingness to behave in a particular way and to accomplish a task. This is important because unless there is no desire or like to have a business there will be no base for an argument that is why it is one of the important variables in TPB (Ajzen, 1991). Perceived behavioral control is about the effort need it to perform a behavior. The PBC is the perception of somebody not his/her skills (Ajzen, 2002).

\subsection{Entrepreneurial Intentions: A Behavioral Approach}

The idea of entrepreneurial behavior is significant for researchers in identifying entrepreneurial intentions, there is a developing need to promote enterprising capacities to manage current difficulties and the questionable future. In the current financial circumstance, occupations are seldom "forever", and conventional secure vocation ways have vanished (Heinonen, 2007). One of the frequently used antecedents of job creation is the importance of entrepreneurial intentions. In his findings, Kolvereid (1996) claims that the stronger an individual's PBC, the greater is that individual purpose to pursue his own business and become self-employed as intention. As indicated by Kickul et al. (2008) self-adequacy has been found to fundamentally impact entrepreneurial behavior and supporting business understudies' 
self-viability is in this manner a critical apparatus in business venture schooling to upgrade understudies pioneering expectations. Entrepreneurial intentions aim has been portrayed "as a cognizant perspective that coordinates consideration" and along with these lines' insight and activity toward a particular article or pathway to accomplish it (Bird, 1989). Hamidi et al. (2008) showed a solid impact of creativity on enterprising aim. The imagination was seen as an idea that is more proactively arranged than elements like apparent conduct control, seen accepted practices, and hazard taking affinity. They likewise found that understudies occupied with scholastic business programs have higher goals to begin their organizations later on. About this, they contended that it would be of worth to analyzing innovative good examples in each instructive setting since those outcomes demonstrate critical differences between in pioneering expectation between various educational fields.

\section{Methodology}

Using a particular research method is to analyze the data based on the right technique (Saunders, Lewis \& Thornhill, 2009). In this research, the positivist approach has been chosen as the research is based on the primary data collection quantitively. When asking about individuals' opinions, it is suggested survey is one of the best methods for data collection (Anol, 2012). A survey got distributed among students of the public universities in Erbil, containing 5 departments of Business, Accounting, Tourism, Banking, and Economy and 219 students from the 5 mentioned department filled the questionnaire. A questionnaire was used by (Linan \& Chen, 2009) for both theory of planned behavior and entrepreneurial intentions based on 1-7 Likert scale, TPB the were 14 items for three variables such as perceived attitude, subjective norms, and perceived behavioral control and 6 items in entrepreneurial intention as indicators. The questionnaire was on Google Forms and was shared with the students. Apart from the validated questionnaire, the researcher also asked four questions about participants' profiles (students) and two other self-administrated questions one to know about student's entrepreneurial competency level and challenges they face in a European country. The aim of choosing a European country was to understand whether there are differences between two different contexts in terms of the TPB variables' effect/relationship on EI indicators or not. The data were analyzed by using SPSS V. 25, tools of analysis were frequencies, correlation, and regression.

\section{Data Analysis}


Table 1: Participants' profile

\begin{tabular}{|l|l|l|l|}
\hline Demographic Info & Items & Frequency & Percentage \\
\hline \multirow{3}{*}{ Gender } & Male & 164 & 74.9 \\
\cline { 2 - 4 } & Female & 55 & 25.1 \\
\hline \multirow{3}{*}{ Age } & $18-24$ & 77 & 35.2 \\
\cline { 2 - 4 } & $24-28$ & 142 & 64.8 \\
\hline \multirow{5}{*}{ Field of Study status } & Single & 181 & 82.6 \\
\cline { 2 - 4 } & Married & 38 & 17.4 \\
\cline { 2 - 4 } & Business & 115 & 52.5 \\
\cline { 2 - 4 } & Accounting & 25 & 11.4 \\
\cline { 2 - 4 } & Tourism & 21 & 9.6 \\
\cline { 2 - 4 } & Banking & 15 & 6.8 \\
\cline { 2 - 4 } & Economy & 53 & 19.6 \\
\hline & Total & 219 & $100 \%$ \\
\hline
\end{tabular}

The above Table (1) describes students' demographics. Out of 219 students, there was $74.9 \%$ male and $25.1 \%$ were female. The second question was about the students' age, in which, majority of them were between 24-28 represented 64.8\%, whereas only 35.2\% were between 18-24 years old. Marital status, majority of students were single as $82.6 \%$ and 17.4 are married. The last question was about the field of study, there are five departments from participants which majority of students are from the business department and after comes economy, then comes from the accounting department and 21 students were from tourism department and 15 students from banking.

Table 2: Students' General information on the entrepreneurial competencies

\begin{tabular}{|l|c|c|}
\hline Items & Frequency & Percent \\
\hline I don't have any info on entrepreneurial competencies & 14 & 6.4 \\
\hline I have a little info on entrepreneurial competencies & 24 & 11.0 \\
\hline I have info on entrepreneurial competencies & 102 & 46.6 \\
\cline { 1 - 1 } I have good and enough information on entrepreneurial & 64 & 29.2 \\
competencies & 15 & \\
\cline { 1 - 1 } I have full info on entrepreneurial competencies and can & & 6.8 \\
start my own business & & \\
\hline Total & 219 & 100.0 \\
\hline
\end{tabular}

According to (Al Mamun et al., 2016) training and skills that students receive from the universities will have a significant impact on entrepreneurial intention. They also found students exposed to entrepreneurial training and courses can improve entrepreneurial competencies. Education is one of the means of perceiving entrepreneurial competencies. The above table discloses that the majority of students acquired enough competencies and the reason that researcher asked the above-administrated question was to understand the participants level of KSAs received from the university, which is one of the forces of intentions to pursue an initial business idea. About $17.4 \%$ of students were not having enough information and $72.6 \%$ have good and full information about the competencies needed to become an entrepreneur. 
Table 3: Entrepreneurial challenges among students

\begin{tabular}{|l|c|c|}
\hline Items & Frequency & Percent \\
\hline I do not have family support. & 26 & 11.8 \\
I do not have enough self-confidence & 45 & 20.5 \\
\hline I could not get enough entrepreneurial education & 21 & 9.5 \\
\hline $\begin{array}{l}\text { I cannot get enough support from government to finance my } \\
\text { business }\end{array}$ & 27 & 12.2 \\
\hline $\begin{array}{l}\text { I have enough: education, self-confidence, family and } \\
\text { government support }\end{array}$ & 100 & 45.6 \\
\hline Total & 219 & 100.0 \\
\hline
\end{tabular}

The above table aimed to identify some challenges students face after getting enough entrepreneurial competencies. There are common challenges globally such as business idea generation, building team, competition, customers, location, etc., but in this particular research, the emphasis is on challenges before starting a new business as an entrepreneur so the factors that affect entrepreneurs asked were family and government support, education and self-confidence. Out of 219 students, only 26 were having difficulties in getting family support, and 27 not having government support. The main challenge students face was not having enough self-confidence. In terms of receiving entrepreneurial education, 198 received enough educational background of entrepreneurship. Out of 219 students 100 of them chose none of the above challenges, this does not mean there are no other challenges maybe this could be due to the question focused on only those but entrepreneurship and forming a new business is not without challenges otherwise everyone would be one.

Table 4: Correlations

\begin{tabular}{|c|c|c|c|c|c|}
\hline & & PA & $\mathrm{SN}$ & PBC & EI \\
\hline \multirow[t]{3}{*}{ PA } & Pearson Correlation & 1 & $.416^{* *}$ & $.505^{* *}$ & $.661^{* *}$ \\
\hline & Sig. (2-tailed) & & .000 & .000 & .000 \\
\hline & $\mathrm{N}$ & 219 & 219 & 219 & 219 \\
\hline \multirow[t]{3}{*}{$\mathrm{SN}$} & Pearson Correlation & $.416^{* *}$ & 1 & $.142^{*}$ & $.287^{* *}$ \\
\hline & Sig. (2-tailed) & .000 & & .036 & .000 \\
\hline & $\mathrm{N}$ & 219 & 219 & 219 & 219 \\
\hline \multirow[t]{3}{*}{$\mathrm{PBC}$} & Pearson Correlation & $.505^{* *}$ & $.142^{*}$ & 1 & $.709^{* *}$ \\
\hline & Sig. (2-tailed) & .000 & .036 & & .000 \\
\hline & $\mathrm{N}$ & 219 & 219 & 219 & 219 \\
\hline \multirow[t]{3}{*}{ EI } & Pearson Correlation & $.661^{* *}$ & $.287^{* * *}$ & $.709^{* *}$ & 1 \\
\hline & Sig. (2-tailed) & .000 & .000 & .000 & \\
\hline & $\mathrm{N}$ & 219 & 219 & 219 & 219 \\
\hline \multicolumn{6}{|c|}{ **. Correlation is significant at the 0.01 level (2-tailed). } \\
\hline \multicolumn{6}{|c|}{$\begin{array}{l}\text { *. Correlation is significant at the } 0.05 \text { level }(2 \text {-tailed). } \\
\text { PA= Perceived Attitude, } \mathrm{SN}=\text { Subjective Norms, } \mathrm{PBC}=\text { Perceived Behavior Control, } \\
\text { EI= Entrepreneurial Intentions, }\end{array}$} \\
\hline
\end{tabular}


In Correlation Table (4), which is used as one of the statistical tools in the identification of the relationship between independent variables and dependent variable, it shows the association between perceived attitude and entrepreneurial intentions as $\left(.661^{* *}\right)$ positively correlated. This means in the case of any increase in perceived attitude, there will be a constructive increase in the entrepreneurial intentions. The association between subjective norms and entrepreneurial intentions is $(.287 * *$ statistically significant of $.000, \mathrm{n}=219)$ statistically significant with a weak association. The relationship between the third variable of the theory of planned behavior which is perceived behavior control with the entrepreneurial intentions is the strongest association comparing to the other two variables of TPB which are (709**).

Table 5: Multi regression analysis

\begin{tabular}{|l|l|l|l|l|l|l|}
\hline \multicolumn{7}{|c|}{ Model Summary } \\
\hline Model & R & R Square & Adjusted R Square & Std. Error of the Estimate \\
\hline 1 & $.792^{\mathrm{a}}$ & .628 & .623 & .79134 \\
\hline \multicolumn{7}{|l|}{ a. Predictors: (Constant), Perceived behavioral control, Subjective norms, Perceived attitude } \\
\hline \multicolumn{7}{|l|}{ ANOVA ${ }^{\mathrm{a}}$} \\
\hline Model & Sum of Squares & df & Mean Square & F & Sig. \\
\hline 1 & Regression & 227.194 & 3 & 75.731 & 120.935 & $.000^{\text {b }}$ \\
\cline { 2 - 7 } & Residual & 134.636 & 215 & .626 & & \\
\cline { 2 - 7 } & Total & 361.830 & 218 & & & \\
\hline $\begin{array}{l}\text { a. Dependent Variable: Entrepreneurial intentions } \\
\text { b. Predictors: (Constant), Perceived behavioral control, Subjective norms, Perceived attitude }\end{array}$ \\
\hline
\end{tabular}

\begin{tabular}{|c|c|c|c|c|c|c|}
\hline \multicolumn{7}{|c|}{ Coefficients $^{\mathrm{a}}$} \\
\hline \multirow{2}{*}{\multicolumn{2}{|c|}{ Model }} & \multirow{2}{*}{\multicolumn{2}{|c|}{$\begin{array}{l}\text { Unstandardized } \\
\text { Coefficients }\end{array}$}} & \multirow{2}{*}{$\begin{array}{l}\text { Standardized } \\
\text { Coefficients } \\
\text { Beta } \\
\end{array}$} & \multirow[t]{2}{*}{$\mathrm{t}$} & Sig. \\
\hline & & & & & & \\
\hline \multirow{6}{*}{1} & (Conctant) & 288 & 286 & & 1007 & \\
\hline & & & & & & 5 \\
\hline & Perceived attitude & .436 & .060 & .380 & 7.213 & .00 \\
\hline & & & & & & 0 \\
\hline & Subjective norms & .054 & .044 & .057 & 1.234 & .21 \\
\hline & $\begin{array}{l}\text { Perceived behavioral } \\
\text { control }\end{array}$ & .561 & .053 & .509 & 10.515 & $\begin{array}{l}.00 \\
0\end{array}$ \\
\hline
\end{tabular}

a. Dependent Variable: Entrepreneurial intentions

Model summary (R) as "multiple correlation coefficient" is the estimated measure of the independent variable (TPB) as (.792a). (R) square of the difference in the entrepreneurial intentions that has been clarified by the theory of planned behavior variables is $(62.3 \%)$ of the IV is justified by the DV. The ANOVA table shows IV as (TPB) is significant in predicting the DV as (EI), the model is a good fit, F (3, $215)=120.935$, $\mathrm{P}$ of $.000 \mathrm{~b})$. 


\section{Findings and Conclusion}

In this research findings are not suppressing that the theory of planned behavior positively affects and has a positive relationship with entrepreneurial intentions, but findings from the correlation and regression show that there are differences in both effect and relationship between two different contexts. In previous research by the same researcher (Ali, 2021) findings of the independent variables such as perceived attitude, subjective norms, and perceived behavioral control were having (.636**, 313**, and 587**) correlation with the entrepreneurial intentions respectively, and $51.3 \%$ of entrepreneurial intention was explained by the theory of planned behavior. From the below table (6) we can see that all hypotheses are accepted with different results comparing to the previous study by (Ali, 2021).

Table 6: Hypotheses acceptance/ rejection

\begin{tabular}{|c|c|c|c|c|}
\hline Hypotheses & $\begin{array}{c}\text { Independent } \\
\text { variable }\end{array}$ & Dependent variable & Effects/Correlation & Result \\
\hline H1 & $\begin{array}{c}\text { Theory of Planned } \\
\text { Behavior }\end{array}$ & $\begin{array}{c}\text { Entrepreneurial } \\
\text { Intentions }\end{array}$ & $\mathrm{R}=.628$ & Accepted \\
\hline H2 & Perceived Attitude & $\begin{array}{c}\text { Entrepreneurial } \\
\text { Intentions }\end{array}$ & $\mathrm{PC}=.661^{* *}$ & Accepted \\
\hline H3 & Subjective Norms & $\begin{array}{c}\text { Entrepreneurial } \\
\text { Intentions }\end{array}$ & $\mathrm{PC}=.287^{* *}$ & Accepted \\
\hline $\mathrm{H} 4$ & $\begin{array}{c}\text { Perceived } \\
\text { Behavioral Control }\end{array}$ & $\begin{array}{c}\text { Entrepreneurial } \\
\text { Intentions }\end{array}$ & $\mathrm{PC}=.709^{* *}$ & Accepted \\
\hline
\end{tabular}

Independent variables such as perceived attitude, subjective norms, and perceived behavioral control are having (. 661**, 287**, and $709^{* *}$ ) of association with entrepreneurial intentions respectively, and $62.8 \%$ of the dependent variable (entrepreneurial intentions) is predicted and explained by the independent variables (theory of planned behavior). The differences are in the private universities, the perceived attitude has a better correlation with entrepreneurial intention, whereas in public universities, perceived behavioral control had better effect and the impact of TPB on EI is more in the public universities comparing to private universities.

Another question answered is about $17.4 \%$ of students were not having enough information about the entrepreneurial competencies and $72.6 \%$ have good and full information needed to become entrepreneur, and the main challenges, out of 219 students only 26 were having difficulties in getting family support and 27 not having government support. The main challenge students face was not having enough selfconfidence. In terms of receiving entrepreneurial education, 198 got enough educational background of entrepreneurship. The findings of this particular study do not mean there are no other challenges maybe this could be due to the questions focused on but entrepreneurship and forming a new business is not without challenges otherwise everyone would be one. 


\section{References}

Ahktar, N., Azeem, S.M., \& Mir, G.M. (2014). Strategic role of internet in SMEs growth strategies. International Journal of Business Management and Economic Research, 5(2), 20-27.

Ajzen, I. (1991). The theory of planned behavior. Organizational Behavior and Human Decision Processes, 50(2), 179-211. https://doi.org/10.1016/0749-5978(91)90020-t

Ajzen, I. (2002). Perceived behavioral control, self-efficacy, locus of control, and the theory of planned behavior. Journal of Applied Social Psychology, 32(4), 665-683. https://doi.org/10.1111/j.1559-1816.2002.tb00236.x

Al Mamun, A., Binti Che Nawi, N., Dewiendren, A., \& Fazira Binti Shamsudin, S. (2016). Examining the effects of entrepreneurial competencies on students' entrepreneurial intention. Mediterranean Journal of Social Sciences. https://doi.org/10.5901/mjss.2016.v7n2p119

Ali, F. A. (2021). The impact of TPB on entrepreneurial intentions. Eurasian Journal of Management \& Social Sciences, 1(3) 1-7.

Anol Bhattacherjee. (2012). Social science research: Principles, methods, and practices (2 ed.). Florida, USA: USF Tampa Library Open Access Collections.

Baruch Y., Gregoriou A. (2017). The impact of people management: Employees' satisfaction role in predicting financial performance. Academy of Management Proceedings, 1.

Bird, B.J. (1989). Entrepreneurial Behavior, Scott Foresman, Glenview, IL.

Cuervo A., Ribeiro D., \& Roig S. (2007). Entrepreneurship: Concepts, theory and perspective, Springer, Madrid.

Engle, R., Dimitriadi, N., Gavidia, J., Schlaegel, C., Delanoe, S., \& Alvarado, I. et al. (2010). Entrepreneurial intent. International Journal of Entrepreneurial Behavior \& Research, 16(1), 35-57. https://doi.org/10.1108/13552551011020063

Fuller, B., Liu, Y., Bajaba, S., Marler, L. E., \& Pratt, J. (2018). Examining how the personality, selfefficacy, and anticipatory cognitions of potential entrepreneurs shape their entrepreneurial intentions. Personality and Individual Differences, 125, 120-125.

Hamidi, D., Wennberg, K., \& Berglund, H. (2008). Creativity in entrepreneurship education. Journal of Small Business and Enterprise Development, 15 (2) 304-20.

Heinonen, J. (2007). An entrepreneurial-directed approach to teaching corporate entrepreneurship at university level. Education+Training, 49 (4), 310-24.

Honig, B. (2004). Entrepreneurship education: toward a model of contingency-based business planning. Academy of Management Learning and Education, 3(3): 258-273.

Kickul, J., Wilson, F., Marlino, D. and Barbosa, S. (2008). Are misalignments of perceptions and selfefficacy causing gender gaps in entrepreneurial intentions among our nation's teens? Journal of Small Business and Enterprise Development, 15 (2), 321-35.

Kolvereid, L. (1996). Prediction of employment status choice intentions. Entrepreneurship Theory and Practice, 21(1), 47-57.

Liñán, F. (2008). Skill and value perceptions: How do they affect entrepreneurial intentions? International Entrepreneurship and Management Journal, 4(3), 257-272. https://doi.org/10.1007/s11365-008-0093-0

Linan, F., \& Chen, Y. (2009). Development and cross-cultural application of a specific instrument to measure entrepreneurial intentions. Entrepreneurship Theory and Practice, 33(3), 593-617. https://doi.org/10.1111/j.1540- 6520.2009.00318.x

Okręglicka, M., Haviernikova, K., Mynarzova, M., \& Lemanska-Majdzik, A. (2017). Entrepreneurial intention creation of students in Poland, Slovakia and Czechia. Polish Journal of Management Studies, 15(2), 162-172. doi: 10.17512/pjms.2017.15.2.15 
Olšovská A., Mura L., \& Švec M., (2015). The most recent legislative changes and their impact on interest by enterprises in agency employment: What is next in human resource management? Problems and Perspectives in Management, 13(3).

Pfeifer, S., Sarlija, N., \& Zekic Susac, M. (2016). Shaping the entrepreneurial mindset: Entrepreneurial intentions of business students in Croatia. Journal of Small Business Management, 54 (1), 102-117.

Renko, M., Kroeck, K., \& Bullough, A. (2011). Expectancy theory and nascent entrepreneurship. Small Business Economics, 39(3), 667-684. https://doi.org/10.1007/s11187-011-9354-3

Saunders, M., Lewis, P., \& Thornhill, A. (2009). Research methods for business students. 5th ed. Harlow: Financial Times/Prentice Hall

Sieger, P., \& Monsen, E. (2015). Founder, academic, or employee? A nuanced study of career choice intentions. Journal of Small Business Management, 53(1), 30-57.

Singer, S., Amoros J.E. \& Moska D. (2015). Global entrepreneurships monitor 2014 global report. [Online] Available at: http://www.babson.edu/Academics/centers/blank-center/Entrepreneurial intentions amongst Master of Business students etc global research/gem/Documents/GEM\%202014\%20Global\%20Report.pdf. Accessed: 25 April 2021.

Szafraniec K. (2011). Youth 2011 Poland, the chancellery of the prime minister, Warsaw. Turker D., Selcuk S.S. (2009), Which factors affect entrepreneurial intention of university students. Journal of European Industrial Training. 33 (2).

Walter S.G., Block J.H. (2016). Outcomes of entrepreneurship education: An institutional perspective. Journal of Business Venturing, 31.

Werthes, D., Mauer, R., \& Brettel, M. (2018). Cultural and creative entrepreneurs: Understanding the role of entrepreneurial identity. International Journal of Entrepreneurial Behavior and Research, 24(1), 290-314.

Yıldırım N., Çakır Ö., \& Aşkun O.B. (2016). Ready to Dare? A case study on the entrepreneurial intentions of business and engineering students in turkey. Procedia-Social and Behavioral Sciences, 229. 